University at Buffalo School of Law

Digital Commons @ University at Buffalo School of Law

Journal Articles

Faculty Scholarship

$1-1-2013$

\title{
Typologies of Scholarship on Africa
}

Makau wa Mutua

University at Buffalo School of Law

Follow this and additional works at: https://digitalcommons.law.buffalo.edu/journal_articles

Part of the International Law Commons

\section{Recommended Citation}

Makau w. Mutua, Typologies of Scholarship on Africa, 107 Proceedings of the ASIL Ann. Meeting 189 (2013).

Available at: https://digitalcommons.law.buffalo.edu/journal_articles/643

\section{C) ${ }_{\text {COPYRIGHT }}^{\text {N }}$}

This Article is brought to you for free and open access by the Faculty Scholarship at Digital Commons @ University at Buffalo School of Law. It has been accepted for inclusion in Journal Articles by an authorized administrator of Digital Commons @ University at Buffalo School of Law. For more information, please contact lawscholar@buffalo.edu. 
Last but not least, Erika George analyzed the gender/human rights theme through a thorough review of Penelope Andrews' new book, From Cape Town to Kabul: Rethinking Strategies for Pursuing Women's Human Rights. ${ }^{9}$ One key insight in this book is the concept of conditional interdependence, which argues that women's differences and the different cultural contexts in which they live their lives should be taken into account in rights advocacy. Through this concept she demonstrates how commonalities across different cultures and histories in different transitional societies, such as Afghanistan and South Africa, result in similar challenges for women, e.g., poverty in the realization of rights. She shows that in this context community and shared resources are far more important than is sometimes assumed in approaches to women's rights that emphasize individuality and autonomy. Professor George argues that Penelope Andrews' book shows how scholarship on Africa and international law has gone beyond the traditional paradigms of international legal feminist literature and strategies.

In all, the three presentations provided an excellent backdrop against which a rich conversation with the audience followed. While there is certainly something new out there on Africa and international law, this panel has only began a much broader conversation. Hopefully, other initiatives like this will continue the conversation. This panel showed that the conversation on Africa and international legal scholarship is quickly building on, challenging, and even going beyond the contributionist tradition as the dominant way of thinking about African international law. ${ }^{10}$ This is indeed an exciting time for African international legal scholarship.

\title{
Typologies of Scholarship on Africa
}

\author{
By Makau Mutua*
}

\section{INTRODUCTION}

First, I want to thank the Program Committee Coordinators for this panel, and Professor James Gathii in particular, who deserves hearty congratulations for having been installed as the Wing-Tat Lee Chair of International Law at Loyola several weeks ago.

One thing struck me as odd when I was preparing for this panel: I was unsure about who the subjects of our inquiry were. Africans? Africanists? Or anyone who writes about Africa and international law? Since I could not resolve this problem, I decided that I would first say a few things about each of the constituencies that write on Africa, and focus on their contributions. But I have no doubt that no matter their vantage point and interest, most scholars of Africa and international law have continually added to our fund of knowledge about the continent's complex relationship with international law. I think it is important to segregate, if you will, these constituencies because their perspectives are informed by their locations, and sometimes the interests they represent or care about. In that sense, I believe that context is very important because scholarship can never really be neutral or free of bias—and I don't think bias is a bad thing, by the way.

\footnotetext{
${ }^{9}$ Erika George, "Feminism and the Future of African International Legal Scholarship," infra at 192.

${ }^{10}$ See James Gathii, A Critical Appraisal of the International Legal Tradition of Taslim Olawale Elias, 21 LEIDEN J. INT'L L. 317 (2008).

* Dean, SUNY Distinguished Professor, and Floyd H. and Hilda L. Hurst Faculty Scholar, SUNY Buffalo Law School.
} 


\section{AFrica AND INTERNATIONAL LAW}

As a modern continent, Africa is largely a creation of international law. That is to say, Africa's identity within international law in the era of modernity has been shaped in its encounter with the West, the normative home of international law. In that sense, Africa is an "outsider" to international law: it is, to wit, one of the originally subordinated continents to international law as a means of ordering - and organizing - the exploitation of the globe. So, at the outset, we have to accept a number of basic and unarguable historical facts- that modern international law was inimical to Africa's interests; that modern international law was used to cannibalize Africa's resources and people; and that modern international at best was meant to manage Africa, as indeed was most of what we call the Third World. Thus international law was a project for stamping Africans' sub-humanity, so that they and their resources could be exploited for the benefit of others.

So let us think about the three traumas that define modern Africa. The first is slavery, which was recognized as legal by international law at the time. The second is colonialism, which international law structured, and some might say invented. And the last was the Cold War, post-colonial order in which Africa was split and shared willy-nilly by the West and the East. Now we have entered a fourth era in the relationship between Africa and international law. This is the post-Cold War era, which has been defined by concerns of human rights, all sorts of protection norms, governance, and various market-based economic models. These three moments were either facilitated by international law or enabled by it. The fourth one, the post-Cold War period, is a little more complex, but is largely a continuum in certain respects of the other three because Africa still exists in a subordinated relationship with the West and the emerging economies of the East. The inevitable question that one must then ask is: Why and how could Africa be part of a regime that exploited it?

\section{Constituencies of Scholars on International Law And Africa}

All international legal scholarship in Africa has been influenced by either the moment of encounter with Europe, or what was happening at a particular point in Africa's history. It is what was happening in Africa-and to Africa-that has influenced scholarship on the continent. That is why the vantage points of the scholars are so critical. I will name the key ones here.

The first, and perhaps most important, group is African scholars themselves (those who are based in Africa and abroad). This group is obviously not monogamous. It is very disparate, although it has two main trajectories that I will discuss briefly. The second group is scholars composed of the African Diaspora (and led primarily by scholars in the United StatesProfessor Henry Richardson of Temple Law School is perhaps the best example of this group today). The third group is composed of Africanists - those who for the purposes of my classification are composed of North Americans and Europeans of white descent. You might wonder why I make a distinction between the African Diaspora and Africanists. I do so because of identity politics and normative affinities as defined by the subordinated location of the African Diaspora versus the privileged standing of white Africanists. I know there is a debate about this, but those who have studied Africa long enough know the phenomenon I am referring to.

There is another constituency of thinkers who are not scholars per se, but who engage in research on Africa. Here I am referring to policy researchers in Western think tanks and certain government offices. This group generally sees Africa as a pawn in a larger Western 
geopolitical strategy (so that its work is really about Empire and how Africa's posture and politics affect the interests of the Empire). This group's major concern is largely how the West maintains its hegemony by leveraging its policies towards Africa. I think the Council on Foreign Relations best typifies this group.

\section{StReAms OF SCHOLARSHIP}

I think the best way to understand and characterize international legal scholarship on Africa is not only by segmenting it by the constituency of scholars, but particularly by historical period. Thus, the early scholarship on Africa and international law dealt with the colonial moment and whether and how Africa could enter the community of nations and leverage existing regimes, or transform them to cater to its own interests. Here, at the dawn of the Independence Decade, there was much hope and optimism in Africa and its potential. Mostly newly minted African states sought entry into the world community on an equal footingexemplified most poignantly by membership in the United Nations. African scholars held a dichotomous view on whether or how the continent could leverage its status of juridical equality with other states. Many were clearly accomodationist-seeking to understand the system and effectively participating in it without necessarily questioning its basic norms and whether they were biased against Africa. This group sought inclusion without being critical of the normative edifice of international law (many African states adopted this view early on).

But another group of African scholars was highly critical of the international legal regime and questioned its capacity for fairness (scholars like Professor Issa Shivji of Tanzania or jurists like Mohamed Bedjaoaui come to mind). As African states experienced structural and normative barriers for entry into the global system, the tone of the continent's scholars turned increasingly critical of international law. These problems were exacerbated by the collapse of African universities in the 1970s and 1980s due to regime instability and state decay through coups usually backed by the West or East and economic stagnation in spite of enormous natural resources. In other words, the optimism of the early independence period evaporated sooner than one expected, in part due to the inability of the African post-colonial state-itself an artificial construct- to cohere into a nation amidst a hostile international system.

A decade into independence, African international legal scholars were convinced that the international legal regime, as constituted, would not be part of Africa's liberation from economic and political bondage. These protest scholars, many of them with a leftist ideological hue, spawned a new generation of critical thinkers. That is why they-and African statesturned to dialogues focused on South-South, and the New International Economic Order. But political efforts for a more equitable international order were blunted by the West and the reassertion of the primacy of the Bretton Woods institutions in African states through structural adjustment programs and other neo-conservative and neo-liberal markets measures. In the midst of this ideological fight, Africanists in the West focused largely on the failures of the African state, without necessarily implicating the international order.

In the late 1970s and 1990s, African international legal scholars-many of them with intellectual roots in the left-increasingly turned to the equal protection language of the human rights project. This was partly a response to the collapse of the Soviet and socialist models as alternatives. Some, like Justice Keba Mbaye, tried to imbue human rights with an African fingerprint. Many sought to use human rights as a language to disrupt neo-colonial abusive regimes still in cahoots with international capital and their Western sponsors. Their focus was - and remains-to rewrite the internal charters of African states and African 
regional bodies (ECOWAS, AU, EAC, SADCC, COMESA, the African regional human rights system) to recover the African state. The idea was to reconstitute the fabric of the state by deploying home-grown liberal norms and through African institutions. These scholars now focus on questions of regional economic integration, technology innovation, gender equality, international criminal law (ICC, Rwanda, Sierra Leone), and local entrepreneurship.

\title{
The Future
}

In the midst of these changes and contestations, younger African scholars have latched on to TWAIL, which is both rejectionist and reconstructionist (it rejects the racist roots of international law and its exploitative normative assumptions) and seeks to reconstruct a more equitable international legal regime. The African university is again on the ascendant—as evidenced by the works of Professor Peter of Tanzania, Professors Sylvia Tamale and Joe Oloka Onyango of Uganda, and so many others in West Africa. Many of them look inward and often collaborate with post-colonial scholars in the West. Their project remains one of an uneasy relationship with international law.

\section{Feminism and the Future of African INTERNATIONAL LEgal SchOLARSHIP}

\author{
By Erika George*
}

Since the American Journal of International Law published the ground-breaking article, "Feminist Approaches to International Law' by Professors Hillary Charlesworth, Christine Chinkin, and Shelley Wright in 1991, there has been significant increase in the material written about the ways in which international law has failed to take account of the challenges faced by women or to appreciate women as relevant. The aim of the article was to urge a rethinking and revising of the structures and principles that exclude most women's experiences. It highlighted the fact that feminism in the Third World was doubly at odds with the dominant male discourse in society. As feminist approaches gained appreciation in the academy and women gained power in the policy arena, divisions appeared over difference. While there was great interest on the part of Western feminists to intervening to halt harmful cultural practices that injured women, there was less appreciation for the work of African women activists and writings published by women from Africa and the African Diaspora. A new literature acknowledging the insights of earlier scholars seeks to address the differences that have divided feminists over questions of difference and invites the women's human rights movement to reconsider the myriad ways in which women on the continent and in other developing countries could secure the equal dignity promised in international human rights instruments not by demanding autonomy but by strategically deploying social connections.

In her book, From Cape Town to Kabul: Rethinking Strategies for Pursuing Women's Human Rights, Dean Penelope Andrews proposes the concept of "conditional interdependence"' as a way of dealing with the difficulty of gender inequality across cultural differences. She presents conditional interdependence as a new frame for fashioning strategies to provide a pragmatic and possibly successful way out of a central challenge that confronts so many women's rights activists around the world—claims that culture, tradition, or religion require

\footnotetext{
${ }^{*}$ Professor of Law and Co-Director, Center for Global Justice, S.J. Quinney College of Law, University of Utah.
} 